\title{
Cytological alterations in the liver of rainbow trout Oncorhynchus mykiss after prolonged exposure to low concentrations of waterborne endosulfan
}

\author{
Helge Arnold ${ }^{1}$, Hans-Jürgen Pluta ${ }^{2}$, Thomas Braunbeck ${ }^{1, *}$ \\ 'Department of Zoology I, University of Heidelberg, Im Neuenheimer Feld 230, D-69120 Heidelberg, Germany \\ ${ }^{2}$ Institute for Water, Air and Soil Hygiene, Federal Environmental Protection Agency, Experimental Station Marienfelde, \\ Schichauweg 58, D-12307 Berlin, Germany
}

\begin{abstract}
In order to elucidate sublethal cytopathological alterations in hepatocytes, mature male rainbow trout Oncorhynchus mykiss were exposed to 1, 10,50, and $100 \mathrm{ng} \mathrm{l}^{-1}$ technical grade endosulfan (Thiodan ${ }^{\mathrm{M}}, 70 \% \alpha$ - and $30 \% \beta$-isomers) for $28 \mathrm{~d}$. Whereas stereological parameters, i.e. relative volumes and numbers of cell organelles, were unaffected, qualitative ultrastructural alterations were detectable from $10 \mathrm{ng} \mathrm{l}^{-1}$ endosulfan. The No-Observed-Effect Concentration (NOEC) for cytological alterations was determined to be $1 \mathrm{ng} \mathrm{J}^{-1}$ endosulfan, i.e. 3 orders of magnitude below the $\mathrm{LC}_{50}$ value Cytological effects that were probably of an adaptive nature included proliferation of SER and circular arrays of RER indicating induction of mixed-function oxygenases (MFO) as well as an increase in lysosomal elements at 50 and $100 \mathrm{ng} \mathrm{l}^{-1}$ endosulfan, probably due to enhanced cellular turnover. In

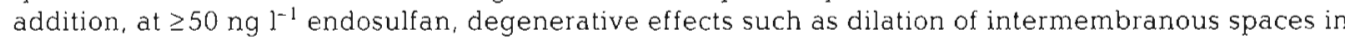
mitochondria, deformation of mitochondria, myelin formation in peroxisomes and cytoplasm, and vesiculation and dilation of RER cisternae were observed. A.lthough there was no indication of specific sublethal modes of toxic action except for MFO induction, the present study indicates that endosulfan has toxic impacts at concentrations of environmental relevance.
\end{abstract}

KEY WORDS: Liver $\cdot$ Endosulfan $\cdot$ Sublethal toxicity $\cdot$ Rainbow trout $\cdot$ Fish $\cdot$ MFO

\section{INTRODUCTION}

The cyclodiene insecticide endosulfan was developed by Hoechst AG in 1954 (Thiodan ${ }^{\mathrm{TM}}$ ) and ranges among the most toxic pesticides for aquatic life, especially fish; it therefore has been registered as a 'priority pollutant' by the US Environmental Protection Agency (Holcombe et al. 1982, Janardan et al. 1984). In a more recent report, the WHO (1986) classified endosulfan in the category of technical products that are moderately hazardous. Acute toxicity for fish $\left(96 \mathrm{~h} \mathrm{LC}_{50}\right)$ varies from $0.1 \mathrm{\mu g} \mathrm{l}^{-1}$ in striped bass Morone saxatilis (Korn \& Earnest 1974) and mosquito fish Gambusia affinis (Joshi et al. 1981) to 20 and $42 \mu^{-1}$ in eel Anguilla anguilla at 29 and $22^{\circ} \mathrm{C}$, respectively (Ferrando et al.

\footnotetext{
- Addressee for correspondence.

E-mail: thomas.braunbeck@urz.uni-heidelberg.de
}

1987). The $\mathrm{LC}_{50}$ in rainbow trout Oncorhynchus mykiss is $1.4 \mathrm{\mu g} \mathrm{l}^{-1}$ (Johnson \& Finley 1980). For reviews on acute toxicity data for endosulfan, see Schimmel et al. (1977), Johnson \& Finley (1980), Goebel et al. (1982), Verschueren (1983), Baier et al. (1985), Mayer \& Ellersieck (1986), and Paul \& Raut (1987).

Particularly in developing countries, endosulfan is in general use for pest control in jute, cotton, sugar cane and vegetable culture. Due to constant leaching, as well as superficial runoff during rainfall and accidental spillage, endosulfan has repeatedly been reported as a contaminant in surface waters of developing countries (Herzel 1972, van Dyk \& Greeff 1977, Wall et al. 1978. Frank et al. 1982, Baier et al. 1985). In the Dutch section of the Rhine River, mean endosulfan concentrations of 0.1 to $0.3 \mathrm{\mu g} \mathrm{l}^{-1}$ have been measured, with maximum values of $0.81 \mathrm{\mu g} \mathrm{l}^{-1}$ occurring in 1969 ; since then decreasing concentrations have been reported 
(Wegmann \& Greve 1978). However, endosulfan has been causally implicated in fish kills in the Rhine River (Braunbeck et al. 1990a, Greve \& Wit 1971). Since bioaccumulation factors of endosulfan in fish may reach values $\geq 1000$ after only $96 \mathrm{~h}$ and $\geq 2000$ after $28 \mathrm{~d}$ (Schimmel et al. 1977, Verschueren 1983), the concentrations measured in the Rhine River after the chemical spill in 1986 (Deutsche Kommission zur Reinhaltung des Rheins 1986) could well be considered a cause of sublethal effects in fish (Braunbeck et al. 1994).

However, in contrast to acute toxicity data, relatively little information exists on the nature and degree of damage to fish after prolonged subacute and sublethal exposure to endosulfan. Pathological changes in brain and liver of fish exposed to endosulfan in the field revealed neurotoxic effecis diung with hepdtocelilular necrosis, oedema and toxic accumulations of lipids (Matthiessen \& Roberts 1982).

In both mammals (Gupta \& Gupta 1979, Tyagi et al. 1985) and fish (Jensen et al. 1991) endosulfan has been shown to function as a phenobarbital-type inducer of cytochrome P-450. In general, fish have repeatedly been shown not to respond to induction by phenobarbital-type compounds (Goksøyr et al. 1987, Kleinow et al. 1987, Gooch et al. 1989, Winston et al. 1989), although they express corresponding cytochrome P-450 IIB genes (Elskus \& Stegeman 1989, Stegeman 1989, Miranda et al. 1990; for nomenclature, see Nebert et al. 1991). Since endosulfan is biotransformed in the liver of fish and excreted via the bile (Schoettger 1970), the liver may be expected to represent a suitable monitor organ for revealing sublethal changes of endosulfan intoxication. In fact, ultrastructural alterations in fish liver have been shown to be of high selectivity and sensitivity in detecting chronic toxicity and underlying toxic mechanism(s) of several groups of chemicals (Hacking et al. 1978, Couch \& Courtney 1987, Hinton et al. 1987). Thus, in the present study ultrastructural alterations in the liver of mature male rainbow trout Oncorhynchus mykiss following subchronic exposure to endosulfan were used (1) to further diagnose the potential hazard by endosulfan in fish, (2) to provide morphological evidence of its potential cytochrome P-450 induction, and (3) to search for specific sublethal modes of action of endosulfan.

\section{MATERIALS AND METHODS}

Fish. Since most fish display pronounced sexual dimorphism in ultrastructural reactions to xenobiotics (Braunbeck et al. 1989), only male fish were used in this study. Mature male rainbow trout had been reared at the Institute for Water, Air and Soil Hygiene (Berlin,
Germany) and were kept in lots of 20 in aquaria containing $220 \mathrm{l}$ of continuously aerated water at $14.5 \pm$ $0.5^{\circ} \mathrm{C}$. Water was replaced in a flow-through system at a rate of $6 \mathrm{l} \mathrm{h} \mathrm{h}^{-1}$ controlled by rotameters. The photoperiod was $12: 12 \mathrm{~h}$. Fish were fed with commercially available trout chow (Trouvit ${ }^{\mathrm{TM}}$ ) at a rate of $1 \%$ body weight. No mortality could be recorded during the acclimation period. Average body weight and length at the beginning of the experiment were estimated to be $300 \mathrm{~g}$ and $30 \mathrm{~cm}$, respectively.

Contaminant and treatment. Technical grade endosulfan (Thiodan ${ }^{\mathrm{TM}}, 70 \% \alpha$ - and $30 \% \beta$-isomers; 6,7 , $8,9,10,10^{\prime}$-hexachloro- $1,5,5 a, 6,9,9$ a-hexahydro- 6,9 methano-2,4,3-benzo-dioxathiepin-3-oxide, CAS no. 115-29-7) was kindly provided by Hoechst (Frankfurt, Germanyj. One mg endosuifan was added to $10 \mathrm{l}$ double-distilled water and vigorously stirred for $24 \mathrm{~h}$ at $20^{\circ} \mathrm{C}$. This stock solution $\left(100 \mu \mathrm{g} \mathrm{l}^{-1}\right)$ was continuously added to the water input of the aquaria by peristaltic pumps to give final concentrations of $1,10,50$, and $100 \mathrm{ng} \mathrm{\textrm {l } ^ { - 1 }}$ endosulfan. Concentrations of stock solutions and actual concentrations in the aquaria were determined by standard gas chromatography (capillary spectrophotometry) after concentration by liquid: liquid extraction; deviations from nominal concentrations were $<10 \%$. After an acclimation period of $14 \mathrm{~d}$ fish were exposed to waterborne endosulfan for $28 \mathrm{~d}$ To control for diurnal variation, all sampling was performed at midmorning.

Electron microscopy. Fish were anaesthetized in 4 -amino benzoic acid ethyl ester (benzocaine; $50 \mathrm{mg} \mathrm{l}^{-1}$ ). In situ cardiac perfusion fixation was accomplished through the ventricular wall using a $3.5 \mathrm{~mm}$ I.D. Tygon $^{\mathrm{TM}}$ tube (Ismatec) and a blunt $1.2 \mathrm{~mm}$ steel needle with a terminal opening of 0.8 to $1.0 \mathrm{~mm}$ (Microlance $^{T M}$; Becton \& Dickinson, Dublin, Ireland). The vasculature was flushed with fish physiological saline $\left(0.9 \% ; 4^{\circ} \mathrm{C}\right)$ containing $2 \%$ polyvinylpyrrolidone (PVP; Merck, Darmstadt, Germany) and 0.5\% procaine hydrochloride (Serva, Heidelberg, Germany) for $30 \mathrm{~s}$ to remove blood cells. This was followed by $1.5 \%$ glutardialdehyde and $1.5 \%$ formaldehyde (freshly prepared from paraformaldehyde) in $0.1 \mathrm{M}$ sodium phosphate buffer ( $\mathrm{pH} 7.6)$ containing $2.5 \%$ PVP $\left(4^{\circ} \mathrm{C}\right)$. Ini-

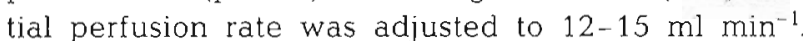
Livers were excised immediately after perfusion, immersed in perfusion fixative for at least $20 \mathrm{~min}$, and cut into slices of 60 to $70 \mu \mathrm{m}$ using an Oxford vibratome. Fixation was continued for $20 \mathrm{~min}$ in $2.5 \%$ glutardialdehyde in $0.1 \mathrm{M}$ sodium cacodylate buffer (pH 7.6) containing 4\% PVP and $0.05 \%$ calcium chloride $\left(4^{\circ} \mathrm{C}\right)$. To distinguish peroxisomes from lysosomes, catalase peroxidatic activity was demonstrated using alkaline 3,3'-diaminobenzidine (DAB; Le Hir et al. 1979): Tissue slices were incubated in $10 \mathrm{mM}$ Teorell- 
Stenhagen buffer ( $\mathrm{pH} 10.0$ ) containing $5 \mathrm{mM}$ DAB and $0.5 \% \mathrm{H}_{2} \mathrm{O}_{2}$ for 60 min at $37^{\circ} \mathrm{C}$ in a shaking water bath. In control experiments, tissue slices were either incubated in an equivalent medium without $\mathrm{H}_{2} \mathrm{O}_{2}$, or preincubated for $30 \mathrm{~min}$ at $4^{\circ} \mathrm{C}$ in $10 \mathrm{mM}$ Teorell-Stenhagen buffer containing $0.2 \mathrm{M} 3$-amino-1,2,4-triazole followed by incubation in the complete DAB medium, which also contained $0.2 \mathrm{M}$ aminotriazole. After repeated rinsing in Teorell-Stenhagen and cacodylate buffers, tissue slices were postfixed for $1 \mathrm{~h}$ with $1 \%$ osmium ferrocyanide (Karnovsky 1971). After washing in $0.1 \mathrm{M}$ cacodylate and $0.05 \mathrm{M}$ maleate $(\mathrm{pH}$ 5.2) buffers, tissues were stained en bloc with $1 \%$ uranyl acetate in maleate buffer for $1 \mathrm{~h}$. Specimens were dehydrated in a graded series of ethanol and embedded in Spurr's medium. Ultrathin sections of 60 to $80 \mathrm{~nm}$ thickness were stained with alkaline lead citrate for $30 \mathrm{~s}$ or $1 \mathrm{~min}$ and examined in a Zeiss EM 9 or a Zeiss EM 10 electron microscope.

Light microscopy. Semithin plastic sections of 0.5 to $0.75 \mu \mathrm{m}$ thickness were stained with methylene blue-Azur II and used for orientation. For visualization of glycogen, semithin sections were incubated in an alkaline $1 \%$ solution of silver diamine for $1.5 \mathrm{~h}$ at $60^{\circ} \mathrm{C}$ (Singh 1964). After rinsing in distilled water, sections were mounted in Entellan and examined in a Leitz Aristoplan photomicroscope.

Stereological analyses. Multistage sampling and morphometrical evaluation were performed according to the principles of Weibel (1979). At all tiers, hepatocytes were selected to serve as a reference space. At each tier, 4 fish per group were evaluated. For details on sampling for stereological analysis, see Table 1.

Volume densities $\left(V_{1}\right)$ were estimated by placing a lattice of $P_{\mathrm{T}}$ test points on micrographs and by determining the fraction $\left(P_{i} / P_{\mathrm{T}}\right)$ of these points enclosed within the profiles of the structure investigated $\left(P_{i}\right)$. Test points falling on extracellular space (biliary tract, sinusoids, endothelia, space of Disse, etc.) were subtracted from the total number of test points. The vol-

Table 1. Magnification of micrographs and stereological parameters investigated with respect to rainbow trout Oncorhynchus mykiss hepatocellular organelles. LM: light microscopy; EM: electron microscopy

\begin{tabular}{|ccll|}
\hline Magnification & $\begin{array}{c}\text { Section } \\
\text { thickness }\end{array}$ & $\begin{array}{l}\text { Volume } \\
\text { density of }\end{array}$ & $\begin{array}{l}\text { Numerical density } \\
\text { (coefficient } b)\end{array}$ \\
\hline $1100 \times($ LM) & $500-700 \mathrm{~nm}$ & $\begin{array}{l}\text { Nuclei } \\
\text { Glycogen }\end{array}$ & Nuclei (1.38) \\
$7200 \times(\mathrm{EM})$ & $150-200 \mathrm{~nm}$ & $\begin{array}{l}\text { Mitochondria } \\
\text { Lysosomes } \\
\text { Lipid droplets } \\
\text { Peroxisomes } \\
\text { RER }\end{array}$ & $\begin{array}{l}\text { Lysosomes (1.38) } \\
\text { Lipid droplets (1.38) }\end{array}$ \\
$18000 \times(\mathrm{EM})$ & $150-200 \mathrm{~nm}$ & Peroxisomes (1.38) \\
& & & \\
\hline
\end{tabular}

ume density of nuclei was determined on light micrographs $(1100 \times)$ using a test point lattice with 391 points spaced at regular intervals $(d)$ of $10 \mathrm{~mm}(=9.091 \mu \mathrm{m})$. For measurement of the volume density of hepatic mitochondria, lipid droplets and lysosomes, electron micrographs $(7200 \times)$ and a test point lattice with 391 points spaced at $d=10 \mathrm{~mm}(=1.388 \mu \mathrm{m})$ was employed. The volume densities of peroxisomes and the endoplasmic reticulum fields were measured on micrographs at a magnification of $18000 \times$ using a test point lattice with 391 points spaced at $d=10 \mathrm{~mm}(=0.555 \mu \mathrm{m})$.

Numerical densities $N_{V}$ of particulate hepatocellular structures within the test area were calculated according to the formula $N_{V}=b^{-1} N_{A}^{1.5} / V_{V}{ }^{05}$ (Weibel 1979), where $N_{\mathrm{A}}$ is the number of actually counted particles divided by the test area, $V_{v}$ is the volume density of the particle and $b$ is a shape-dependent coefficient. This coefficient $b$ was assumed to be 1.38 for lipid droplets, peroxisomes and lysosomes (Weibel 1979). Numerical densities of lipid droplets and lysosomes were calculated from electron micrographs at a magnification of $7200 \times$, that of peroxisomes from micrographs at $18000 \times$.

The numerical density of nuclei $\left(N_{\mathrm{Nu}}\right)$ was used to calculate the volume of hepatocytes: $V_{\text {hep }}=1 / N_{\mathrm{Nu}}$. Absolute volumes and numbers of lysosomes, lipid droplets and peroxisomes and absolute volume of mitochondria per hepatocyte were estimated as $V_{1} \times$ cell volume and $N_{V} \times$ cell volume, respectively. The volumes and total numbers of organelles per hepatocyte were estimated as $V_{V} V_{\text {hep }}$ and $N_{V} V_{\text {hep }}$ respectively. Hepatocytic and nuclear diameters were calculated as the third root of the relevant volumes, assuming a spherical shape of the particles

Rough endoplasmic reticulum (RER) surface densities $\left(S_{V}\right)$ were calculated by using a line test grid $(d=10 \mathrm{~mm})$ as the ratio of twice the number of intersections with RER cisternae to the total length of lines on the hepatocytes being examined (Weibel 1979). Total hepatocellular surface of RER cisternae was estimated as $S_{V} V_{\text {hep. }}$.

Cell components not measured individually mainly included Golgi fields, smooth endoplasmic reticulum (SER), and cytoplasm. Mean values from stereological measurements were compared using Student's double-tailed $t$-test.

\section{RESULTS}

\section{Macroscopic observations}

Following exposure to $1-100 \mathrm{ng} \mathrm{l}^{-1}$ endosulfan, no mortality was observed. However, at $100 \mathrm{ng} \mathrm{l}^{-1}$ endosulfan, male 
rainbow trout showed reduced food intake in the initial phase of the experiment, whereas towards the end of the experiment and at lower endosulfan concentrations no differences from controls were evident.

\section{Liver morphology and stereology}

Qualitative and quantitative alterations of liver ultrastructure in controls and fish exposed to endosulfan are listed in Tables $2 \& 3$.

\section{Controls}

The liver of rainbow trout was characterized by uniform hepatocytes with extended, peripheral glycogen fields clearly separated from an organelle-containing perinuclear and peribiliary area (Fig. 1). Hepatocytes were regularly arranged around bile canaliculi (tubular architecture of rainbow trout liver; cf. Hampton et al. 1985, 1988) and closely associated with sinusoids (Fig. 1). Mean diameter of hepatocytes was $15.6 \pm 0.8$ $\mu \mathrm{m}$; mean volume was about $1990 \mu \mathrm{m}^{3}$ (Table 3). Lipid inclusions were scant.

Table 2. Oncorhynchus mykiss. Semiquantitative analysis of ultrastructural alterations in the liver of rainbow trout following exposure to endosulfan. (Control $=0 \mathrm{ng} \mathrm{l}^{-1}$ of endosulfan). Data are given for 4 fish. Abbreviations: - not present, (+) very little developed, + little developed, ++ moderately developed, +++ sionyily developed

\begin{tabular}{|c|c|c|c|c|c|}
\hline & Control & $1 \mathrm{ng} \mathrm{I}^{-1}$ & $10 \mathrm{ng} \mathrm{l}^{-1}$ & $50 \mathrm{ng} \mathrm{l}^{-1}$ & $100 \mathrm{ng} \mathrm{l}^{-1}$ \\
\hline \multicolumn{6}{|l|}{ Parenchymal organization } \\
\hline Cellular heterogeneity & - & - & - & - & ++ \\
\hline \multicolumn{6}{|l|}{ Nucleus } \\
\hline Irregular outline & + & + & ++ & t+ & +++ \\
\hline Dilation of nuclear envelope & - & - & - & ++ & ++ \\
\hline Two nucleoli & - & - & $(+)$ & ++ & ++ \\
\hline \multicolumn{6}{|l|}{ Mitochondria } \\
\hline Structural integrity & $t+t$ & +++ & +++ & ++ & + \\
\hline Myelin formation in intermembranous space & - & - & - & ++ & +++ \\
\hline Dilation of intermembranous space & - & - & - & ++ & ++ \\
\hline Deformation & - & - & - & - & ++ \\
\hline \multicolumn{6}{|l|}{ Peroxisomes } \\
\hline Structural integrity & +++ & t+t & +++ & t+t & +++ \\
\hline Cluster formation & - & - & - & ++ & ++ \\
\hline Heterogeneity of shape & + & + & ++ & ++ & ++ \\
\hline Heterogeneity of matrix & - & - & - & - & ++ \\
\hline Myelin formation in matrix & - & - & - & - & ++ \\
\hline \multicolumn{6}{|l|}{ Lysosomes } \\
\hline Structural integrity & +++ & +++ & +++ & +++ & +++ \\
\hline Peribiliar localization & ++ & ++ & ++ & $(+j$ & $(+)$ \\
\hline Myelin formation & - & - & - & ++ & ++ \\
\hline Autophagosomes & - & - & + & ++ & +++ \\
\hline Multivesicular bodies & - & - & - & ++ & ++ \\
\hline Cytoplasmic myelin bodies & - & - & - & ++ & ++ \\
\hline \multicolumn{6}{|l|}{ RER } \\
\hline Vesiculation of cisternae & _ & _ & _- & + & + \\
\hline Dilation of cisternae & - & - & + & + & + \\
\hline Parallel stacks of cisternae & +++ & +++ & +++ & +++ & +++ \\
\hline Concentric arrays & - & - & - & + & + \\
\hline \multicolumn{6}{|l|}{ SER } \\
\hline Peribiliar localization & t+ & ++ & ++ & $1+1$ & $(+)$ \\
\hline Localization within glycogen field & - & - & $(+)$ & ++ & +++ \\
\hline Quantity & + & + & + & ++ & +++ \\
\hline \multicolumn{6}{|l|}{ Golgi fields } \\
\hline Structural heterogeneity & - & - & + & ++ & ++ \\
\hline Activity & $++t$ & +++ & +++ & +++ & +++ \\
\hline VLDL particles & +++ & +++ & +++ & ++ & ++ \\
\hline \multicolumn{6}{|l|}{ Storage materials } \\
\hline Lipid & - & - & - & - & - \\
\hline Glycogen & +++ & +++ & +++ & +++ & +++ \\
\hline \multicolumn{6}{|l|}{ Macrophages } \\
\hline Macrophage centers & - & - & - & - & ++ \\
\hline Quantity & - & - & - & t+ & +++ \\
\hline
\end{tabular}


Table 3. Oncorhynchus mykiss. Stereological analyses of ultrastructural alterations in hepatocytes of male rainbow trout following subchronic exposure $(28 \mathrm{~d})$ to 10,50 and $100 \mathrm{ng} \mathrm{l^{-1 }}$ endosulfan. (Control $=0 \mathrm{ng} \mathrm{l}^{-1}$.) Data given as means $\pm \mathrm{SE}$ for 4 fish. Differences of experimental groups from controls were evaluated by Student's double-tailed t-test $(n=4)$

\begin{tabular}{|c|c|c|c|c|}
\hline & Control & $10 \mathrm{ng} \mathrm{l}^{-1}$ & $50 \mathrm{ng} \mathrm{l}^{-1}$ & $100 \mathrm{ng} \mathrm{l}^{-1}$ \\
\hline \multicolumn{5}{|l|}{ Hepatocyte } \\
\hline Total volume $\left(\mu \mathrm{m}^{3}\right)$ & $1990.4 \pm 284.7$ & $2037.9 \pm 223.8$ & $2042.5 \pm 361.2$ & $2054.0 \pm 442.5$ \\
\hline Diameter $(\mu \mathrm{m})$ & $15.6 \pm 0.8$ & $15.7 \pm 0.6$ & $15.7 \pm 0.9$ & $15.7 \pm 1.2$ \\
\hline \multicolumn{5}{|l|}{ Nucleus } \\
\hline Total volume $\left(\mathrm{\mu m}^{3}\right)$ & $135.8 \pm 23.6$ & $128.7 \pm 8.0$ & $144.3 \pm 26.8$ & $111.7 \pm 10.7$ \\
\hline Diameter $(\mu \mathrm{m})$ & $6.4 \pm 0.4$ & $6.3 \pm 0.1$ & $6.5 \pm 0.4$ & $6.0 \pm 0.2$ \\
\hline \multicolumn{5}{|l|}{ Cytoplasm } \\
\hline Total volume $\left(\mu^{3}\right)$ & $1854.6 \pm 265.1$ & $1909.2 \pm 217.6$ & $1898.2 \pm 335.6$ & $1942.3 \pm 436.8$ \\
\hline Nuclear-cytoplasmic ratio & $0.07 \pm 0.01$ & $0.06 \pm 0.00$ & $0.07 \pm 0.00$ & $0.06 \pm 0.01$ \\
\hline \multicolumn{5}{|l|}{ Mitochondria } \\
\hline Total volume $\left(\mu^{3}\right)^{3}$ & $105.3 \pm 9.1$ & $105.6 \pm 11.6$ & $120.9 \pm 28.4$ & $113.3 \pm 13.2$ \\
\hline \multicolumn{5}{|l|}{ Peroxisomes } \\
\hline Total volume $\left(\mu \mathrm{m}^{3}\right)$ & $28.3 \pm 1.6$ & $27.0 \pm 7.8$ & $34.5 \pm 4.9$ & $27.1 \pm 7.5$ \\
\hline Diameter $(\mu \mathrm{m})$ & $0.8 \pm 0.03$ & $0.8 \pm 0.05$ & $0.8 \pm 0.05$ & $0.8 \pm 0.1$ \\
\hline \multicolumn{5}{|l|}{ Lysosomes } \\
\hline Total volume $\left(\mu \mathrm{m}^{3}\right)$ & $10.8 \pm 5.1$ & $16.9 \pm 3.7$ & $6.9 \pm 2.3$ & $12.1 \pm 6.0$ \\
\hline Diameter $(\mu \mathrm{m})$ & $0.8 \pm 0.1$ & $0.9 \pm 0.03$ & $0.7 \pm 0.06$ & $0.7 \pm 0.11$ \\
\hline \multicolumn{5}{|l|}{ RER } \\
\hline Total volume $\left(\mu \mathrm{m}^{3}\right)$ & $516.9 \pm 62.5$ & $505.2 \pm 74.7$ & $535.3 \pm 129.6$ & $460.3 \pm 188.3$ \\
\hline Surface area $\left(\mu \mathrm{m}^{2}\right)$ & $5223.1 \pm 920.8$ & $4352.2 \pm 486.1$ & $4854.7 \pm 1047.8$ & $4869.7 \pm 1440.7$ \\
\hline \multicolumn{5}{|l|}{ Lipid } \\
\hline Total volume $\left(\mu \mathrm{m}^{3}\right)$ & $0.0 \pm 0.0$ & $0.0 \pm 0.0$ & $0.0 \pm 0.0$ & $0.0 \pm 0.0$ \\
\hline \multicolumn{5}{|l|}{ Glycogen fields } \\
\hline Total volume $\left(\mu \mathrm{m}^{3}\right)$ & $737.1 \pm 219.2$ & $740.6 \pm 85.0$ & $711.4 \pm 189.1$ & $672.0 \pm 203.1$ \\
\hline \multicolumn{5}{|l|}{ Other cell components } \\
\hline Total volume $\left(\mu \mathrm{m}^{3}\right)$ & $456.1 \pm 41.7$ & $514.1 \pm 103.0$ & $489.1 \pm 61.8$ & $657.6 \pm 164.0$ \\
\hline
\end{tabular}

The nuclei of hepatocytes were spherical with a mean diameter of $6.4 \mu \mathrm{m}$ and showed slightly corrugated outlines and small amounts of heterochromatin randomly scattered over the nucleoplasm. The slightly eccentric nucleolus was distinctly separated into a pars fibrosa and a pars granulosa. The perinuclear area was characterized by a sheath consisting of stacks of up to 15 non-fenestrated parallel cisternae of the RER. This RER envelope was usually interrupted in the peribiliary area and free of glycogen, but interspersed and bordered by numerous mitochondria and peroxisomes. RER surface area and volume were ca $5200 \mathrm{\mu m}^{2}$ and $500 \mathrm{\mu m}^{3}$, respectively (Table 3). Mitochondria appeared as spherical or elongated profiles with numerous cristae and some intramitochondrial granules. As estimated by stereology, the mean volume of mitochondria was ca $105 \mu^{3}$ (Table 3). Each hepatocyte contained about 600 spherical peroxisomes, which accounted for about $28 \mu^{3}$ of the hepatocellular volume. Peroxisomes were usually closely associated with mitochondria at the outer border of the RER envelope and had a homogeneous, finely granular matrix.

Lysosomes, Golgi fields and SER were concentrated in the peribiliary area of the hepatocytes. SER, typi- cally developed as an irregular network of tubular or vesicular profiles, was restricted to minute areas in the cytoplasm. Golgi fields were small and few in number and possessed 3 to 5 cisternae budding off numerous vesicles containing VLDL (Very Low Density Lipoprotein) granules. Lysosomes were large $(0.8 \pm 0.1 \mu \mathrm{m})$ but few in number (Figs. $1 \& 21$ ), and were restricted to the vicinity of bile canaliculi. Their heterogenous matrix was of high electron density

\section{Livers of fish exposed to endosulfan}

Response in rainbow trout liver to technical grade endosulfan displayed clear dose-dependent cytological effects starting at $10 \mathrm{ng} \mathrm{l}^{-1}$ endosulfan (Table 2). No histological alterations in liver ultrastructure were evident after exposure to $1 \mathrm{ng} \mathrm{l}^{-1}$ endosulfan, thus indicating a No-Observed-Effect Concentration (NOEC) of $1 \mathrm{ng} \mathrm{^{-1 }}$. The uniform appearance of hepatocytes was well preserved up to $50 \mathrm{ng} \mathrm{^{-1 }}$ endosulfan, whereas exposure to $100 \mathrm{ng} \mathrm{l}^{-1}$ endosulfan resulted in conspicuous structural heterogeneity of hepatocytes. However, by stereological methods, only minor quantitative 


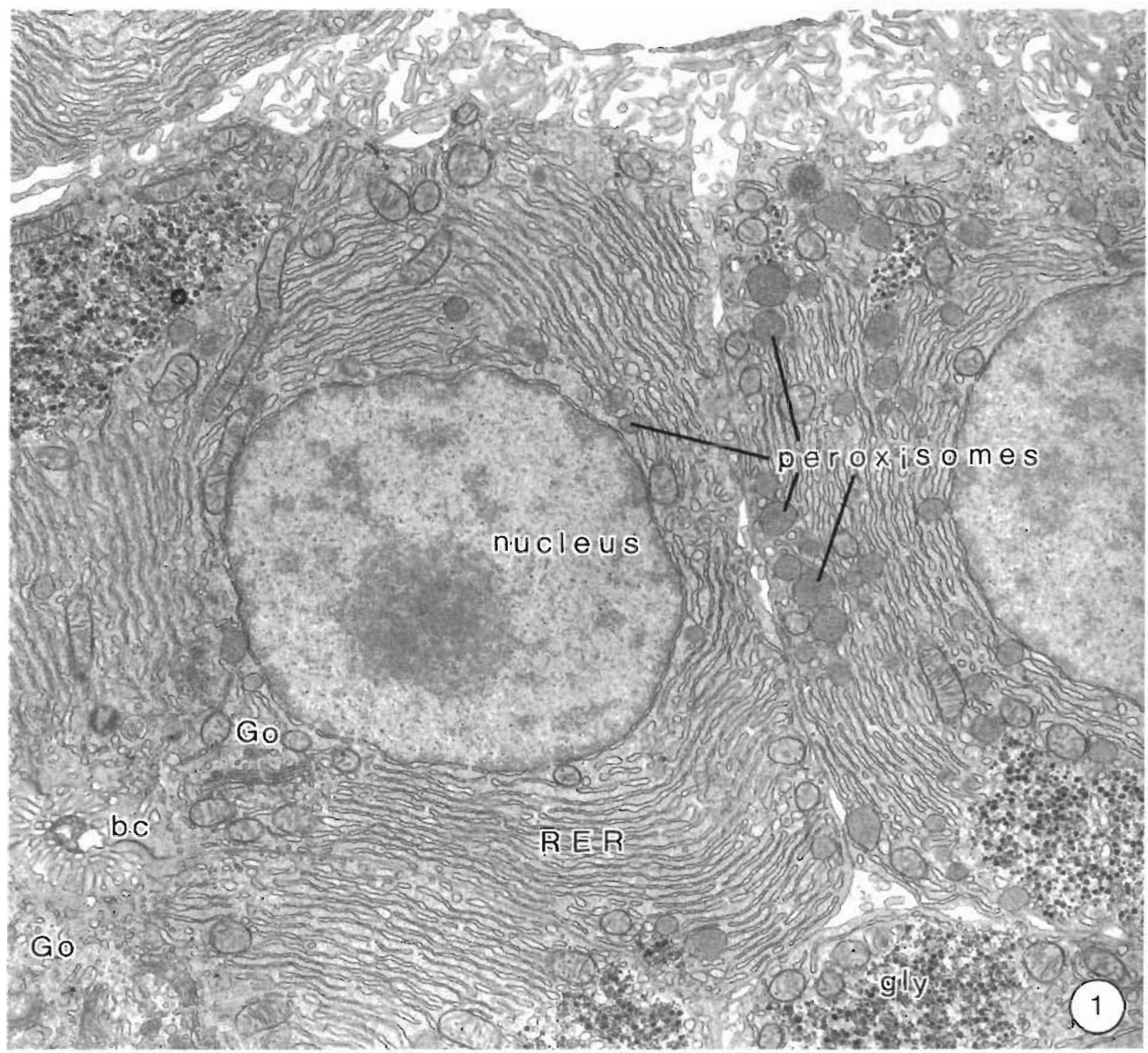

Fig I Oncorhynchus mykiss The ultrastructure of rambow trout liver was characterized by a central nucleus surrounded by extensive stacks of parallel, non-fenestrated, rough endoplasmuc retıculum (RER) bordered by numerous mitochondria and peroxisomes. The RER envelope was interrupted in the peribuliary area, where Golgu fields (Go), smooth endoplasmic reticulum and a small number of lysosomes were located close to the bile canaliculus (bc). gly: glycogen. $8000 x$

changes following exposure to endosulfan could be recorded (Table 3, Figs. $21 \& 22$ ).

Subchronic exposure to $10 \mathrm{ng} l^{-1}$ endosulfan resulted in irregularities of the nuclear outline, amplification of nucleoli and an increase in structural heterogeneity of peroxisomes and Golgi fields. Furthermore, a few autophagosomes and a slight dilation of RER cisternae were discernible (Table 2) Following exposure to $\geq 50 \mathrm{ng} \mathrm{l}^{-1}$ the endosulfan effects already described for $10 \mathrm{ng} \mathrm{l}^{\cdot 1}$ endosulfan occurred, but were generally more pronounced (Table 2). In addition, from $50 \mathrm{ng} \mathrm{l}^{-1}$ onwards, the nuclear envelope appeared dilated and less regular ( $F 1 g$ 2). The RER basically preserved its regular arrangement in parallel stacks (Figs. 2 \& 3). In contrast, dilation of cisternae, as was already evident from $10 \mathrm{ng} \mathrm{l}^{-1}$ endosulfan, was associated with slight vesiculation (Figs. $2 \& 3$ ) and formation of concentric arrays of RER cisternae. In addition, the relative volume of RER stacks slightly decreased from $26 \%$ in controls to about $22 \%$ following exposure to $100 \mathrm{ng} \mathrm{l}^{-1}$ endosulfan (Flg 22). The SER was clearly increased in volume from $50 \mathrm{ng} \mathrm{l}^{-1}$ endosulfan, with the strongest induction at $100 \mathrm{ng} \mathrm{l}^{-1}$ endosulfan (Table 2, semiquantitative data). In conjunction with the induction, SER profiles spread from the peribiliary area to a wider distribution withın glycogen fields (Fig. 4) 
Effects in peroxisomes comprised cluster formation (Figs. 5 \& 6) and, at $100 \mathrm{ng} \mathrm{l}^{-1}$ only, an increased heterogeneity of the matrix partly accompanied by conspicuous intraperoxisomal myelin formations (Fig. 7). Due to considerable variability in the stereological data, no changes could be documented in number and relative volume of peroxisomes (Figs. 21\& 22).

Mitochondria displayed severe loss of structural integrity as a result of myelin formation and dilation of the intermembranous space (Figs, 8 to 10). After exposure to $100 \mathrm{ng}^{-1}$ endosulfan only, mitochondria became severely deformed (Fig. 10). Agaın, however, no significant changes were seen in the stereological parameters for hepatocellular mitochondria following endosulfan exposure (Table 3, Figs. 21 \& 22). Mean and relative volumes were similar to controls or only slightly changed, to a maximum of $120 \mu^{3}$ and $5.9 \%$ at $50 \mathrm{ng} \mathrm{l}^{-1}$ endosulfan, respectively.

Lysosomes showed major morphological changes due to higher endosulfan exposure levels when compared to controls and the effects described for $10 \mathrm{ng} \mathrm{l}^{-1}$ endosulfan. As was true for SER, most lysosomes displayed a more random distribution within hepatocytes (Fig. 11). Furthermore, lysosomes with myelin formations (Fig, 12), multivesicular bodies (Fig 15) and cytoplasmic myelinated bodies (Fig. 16) were strongly developed at the 2 highest concentrations tested. The number of autophagosomes showed a clear dosedependent increase (Figs. $13 \& 14$ ) In addition, the relative volume of macrovesicular lysosomes increased to an average of 20 profiles per hepatocyte following $100 \mathrm{ng}^{-1}$ endosulfan (Fig. 21).

Compared to $10 \mathrm{ng} \mathrm{l}^{-1}$ endosulfan, under higher exposures the structural heterogenelty of Golgl fields was further increased and VLDL secretion was reduced, whereas the activity of Golgı fields as estımated by vesicle formation was not affected by endosulfan exposure. Hepatic glycogen contents were not affected by endosulfan and remained at about $700 \mu \mathrm{m}^{3}$ per cell, accounting for $34 \%$ of the hepatocellular volume (Table 3, Fig. 22). As in controls, lipid inclusions were scant.

In addition to hepatocellular changes, numerous macrophages containing large amounts of materials ingested by phagocytosis, mainly in lysosomes and

Figs. 2 to 4. Oncorhynchus mykiss. Typical alterations in rainbow trout hepatocytes due to endosulfan exposure were dilation (Figs. 2 \& 3) and vesiculation (Fig. 3) of rough endoplasmic reticulum (RER) cisternae as well as a slight dulation of the nuclear envelope (Fig. 2). Furthermore, a strong augmentation of smooth endoplasmic reticulum (SER) along with a more random cellular distribution could be observed following endosulfan exposure (Fig. 4). mi: mitochondria Exposure level $=50 \mathrm{ng} \mathrm{l}^{-1}$. Fig. 2: $7400 x_{i}$ Fig. 3: 9100 $x_{i}$ Fig. 4: $14500 \times$
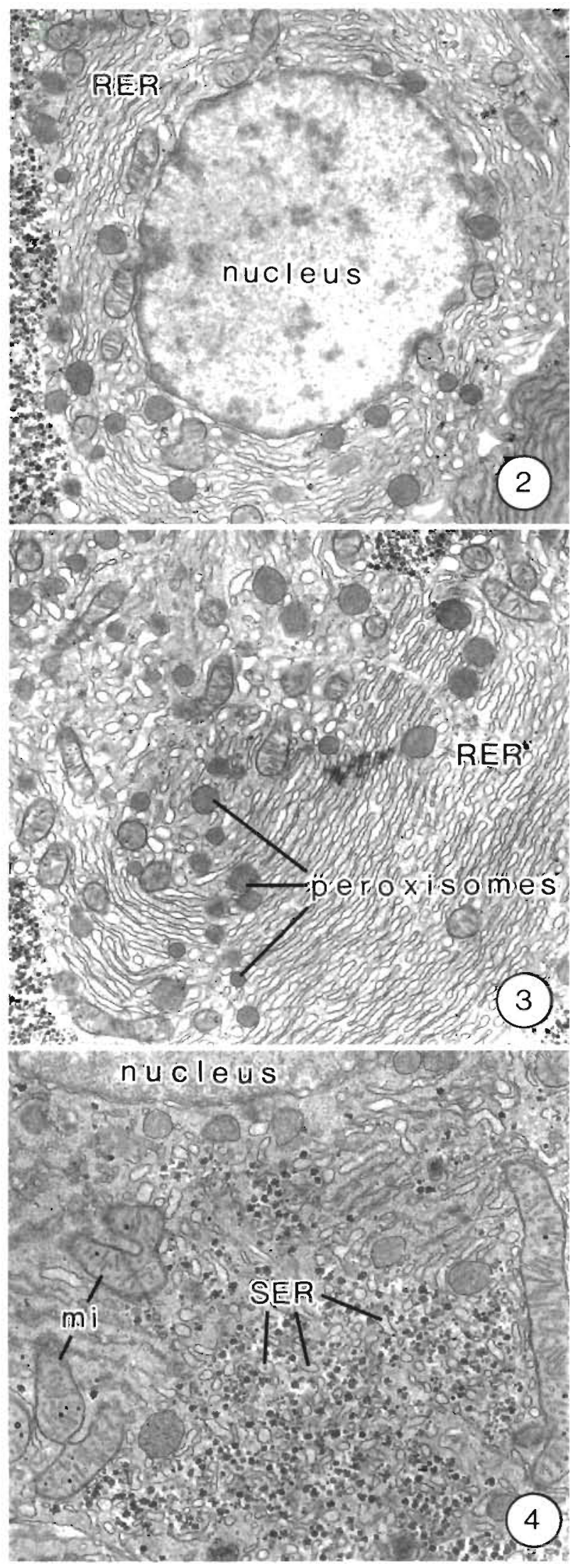

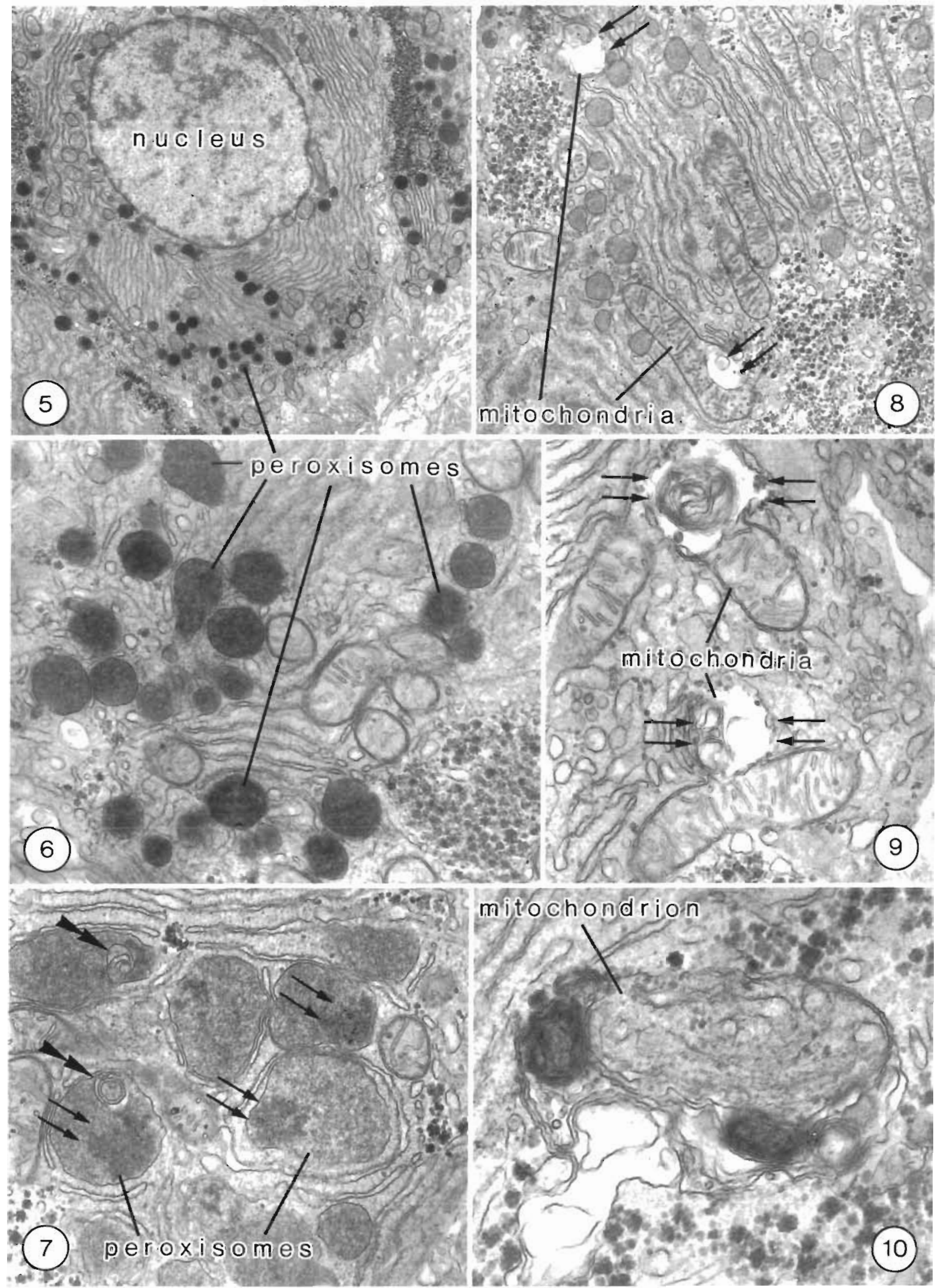

Figs. 5 to 10 Oncorhynchus mykiss Following exposure to $50 \mathrm{ng}^{-1}$ endosulfan. peroxisomes showed a distinct tendency towards cluster formation (Figs $5 \& 6$ ) and increased morphological heterogeneity (Fig 6). At $100 \mathrm{ng} \mathrm{l}^{-1}$ endosulfan, the peroxisomal matnx displayed strong heterogeneity in electron density (cf core-like dense bodies in matrix: Fig. 7, arrows), and small myelin figures spread inwards from the peroxisomal membrane (Fig 7, doubled arrowheads). Further effects by endosulfan included dilation of the intermembranous space of mutochondna (Fig 8 , arrows) and the development of myelin figures in the resulting spaces (Fig 9, arrows) At $100 \mathrm{ng} \mathrm{l}^{-1}$ endosulfan, some of the mitochondna showed strong deformation and highly condensed

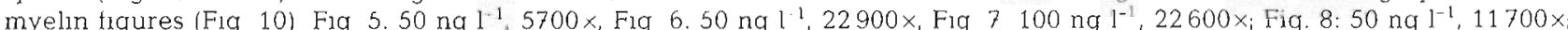

Fig $950 \mathrm{ng} \mathrm{I}^{-1} .30000 \times$, Fig $10100 \mathrm{ng} \mathrm{l}^{-1}, 46400 x$ 


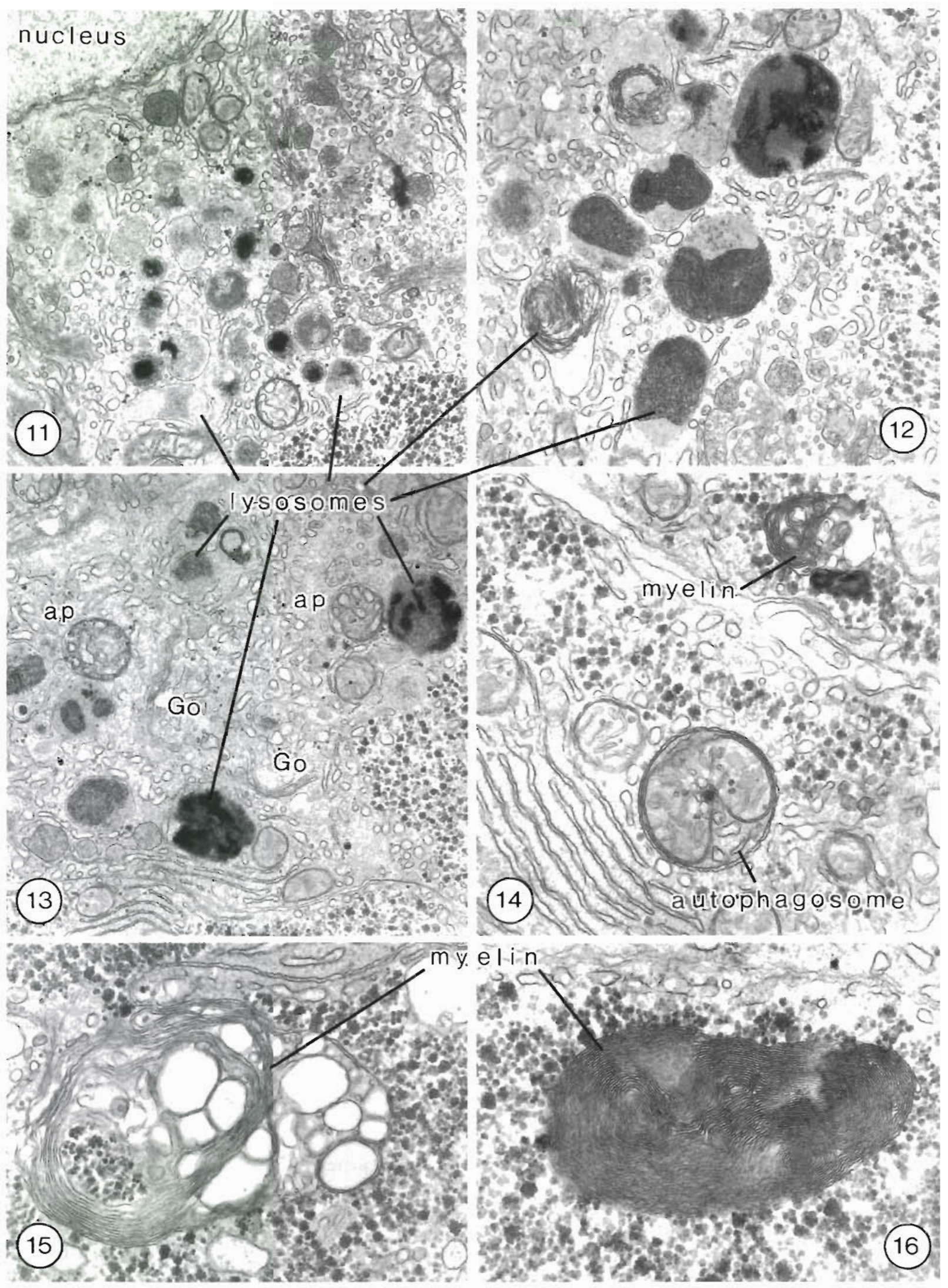

Figs 11 to 16 . Oncorhynchus mykıss. Major pathological alteratıons due to endosulfan exposure were observed in the lysosomal compartment. In addition to shifting from the usual peribiliary location to a more random distribution (Fig. 11), lysosomes developed highly condensed intralysosomal myelın figures (Figs. 12 \& 13). Furthermore, an augmentation of autophagosomes (ap, Fig. 13), which usually were observed degrading hepatocellular mitochondria, could be observed at $50 \mathrm{ng}^{-1}$ endosulfan (Fig 14). Multivesicular bodies (Fig 15) and concentrated myeln bodies (Fig 16) within glycogen fields were conspicuous

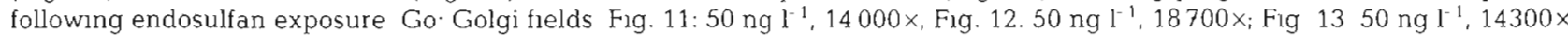

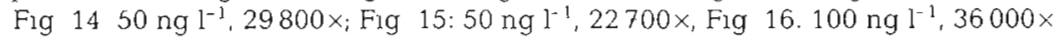




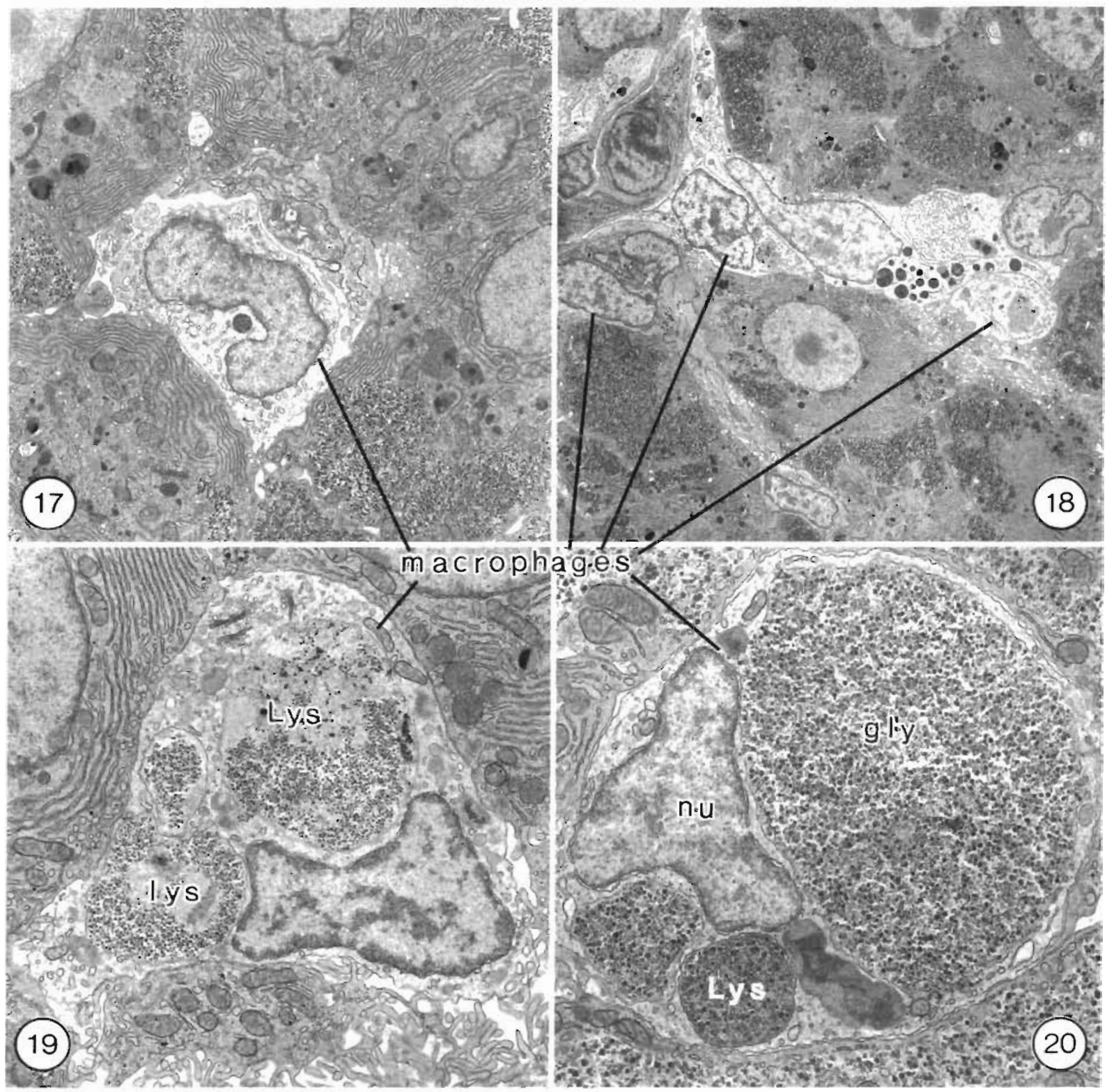

Figs 17 to 20. Oncorhynchus mykiss The immigration of single macrophages at $50 \mathrm{ng}^{1-1}$ endosulfan (Fig. 17) was followed by the development of macrophage centres at higher endosulfan concentrations (Fig 18) Macrophages were characterized by large amounts of ingested materials, especially glycogen, in the electron-lucent cytoplasm (Figs. 19 \& 20). gly: glycogen; lys: lysosomes; nu nucleus of macrophage Fig $1750 \mathrm{ngl}^{-1}, 3700 \times$, Fig $18100 \mathrm{ngl}^{-1}, 1800 x_{1}$. Fig $1950 \mathrm{ng} \mathrm{l}^{-1}, 3700 x_{i}$ Fig. 20: 100 ng l-1,9400x

glycogenosomes, were found at 50 and $100 \mathrm{ng} \mathrm{l}^{-1}$ endosulfan (Figs. 17, $19 \& 20$ ). At $100 \mathrm{ng} \mathrm{l}^{-1}$ endosulfan, groups of up to 5 macrophages per section had formed large macrophage centres (Fig 18).

\section{DISCUSSION}

The toxicity of most organochlonne pesticides often manufests itself by neurological effects such as hyperactivity, muscular twitching or convulsions, resulting in death of animals (WHO 1984). However, no mortality and no such effects were observed in rainbow trout exposed to $10-100 \mathrm{ng} \mathrm{l^{-1 }}$ waterborne endosulfan. In contrast, numerous cytological alterations due to endosulfan exposure were recorded in rainbow trout liver. Effects were observed starting at $10 \mathrm{ng} \mathrm{l}^{-1}$ endosulfan (LOEC, Lowest Observed Effect Concentration), i.e. concentrations 2 orders of magnitude below the $96 \mathrm{~h}$ $\mathrm{LC}_{50}$ of $1.4 \mathrm{\mu g} \mathrm{l}^{-1}$ endosulfan for rainbow trout (Johnson \& Finley 1980) Since $10 \mathrm{ng} \mathrm{l}^{-1}$ endosulfan are within the range of fleld data, these observations are likely to 


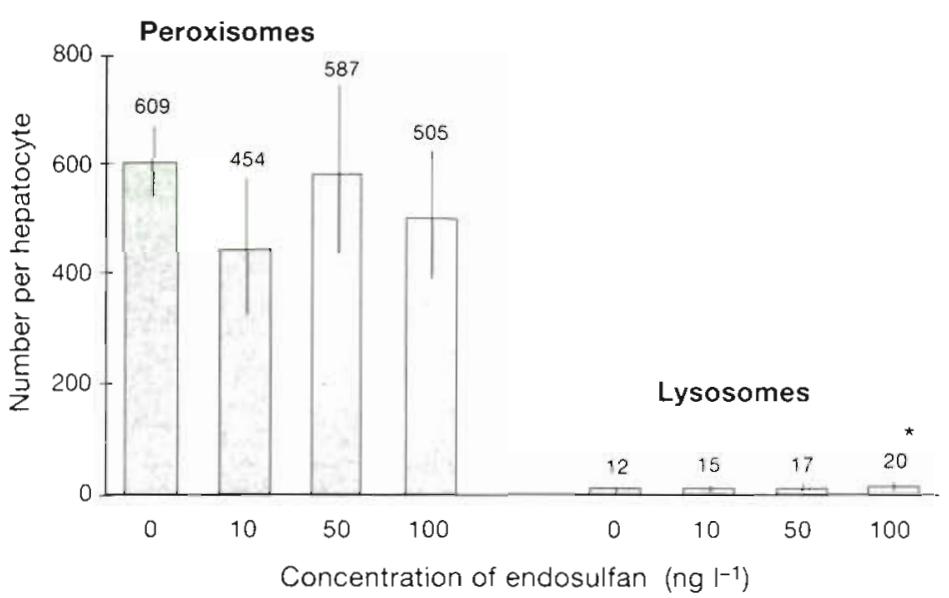

Fig. 21. Oncorhynchus mykiss. Changes in numbers of peroxisomes and lysosomes in hepatocytes of male rainbow trout following exposure to $0,10,50$, and $100 \mathrm{ng} \mathrm{l}^{-1}$ endosulfan for $28 \mathrm{~d} .{ }^{\star} \mathrm{p}<0.05$

be encountered in fish from the field as well. Our results thus confirm earlier conclusions that changes in liver ultrastructure can serve as sensitive biomarkers of exposure to toxicants, integrating a wide spectrum of physiological and biochemical functions of hepatocytes (Hinton \& Laurén 1990, Braunbeck 1994).

In rainbow trout liver, alterations due to endosulfan were clearly dose-dependent, showing adaptive as well as degenerative phenomena. The fact that no severe, strictly pathological effects were found emphasizes the adaptive nature of most cellular responses to endosulfan. This view is also supported by the almost complete lack of change in total volumes as well as relative volumes of peroxisomes, mitochondria and lysosomes, which is generally regarded as a typical reaction in necrotic cells (Bowen 1984, Wyllie et al. 1984). Not even degradation of liver glycogen reserves, which is usually consistent with unspecific stress phenomena due to pesticide exposure (Hanke et al. 1983, Gluth \& Hanke 1985), was observed. This observation contrasts somewhat with studies which have shown glycogen loss in Barbus conchonius (Gill et al. 1991), Channa punctatus (Murty \& Devi 1982, Verma et al. 1983) and Tilapia mossambicus (Dange 1986) following exposure to considerably higher concentrations of endosulfan.

Particularly at concentrations of $10 \mathrm{ng} \mathrm{l}^{-1}$ endosulfan, adaptive changes such as induction of autophagosomes-a sign of increased turnover of cell components-were found, but, from $50 \mathrm{ng}^{-1}$ endosulfan, an increasing number of degenerative effects was seen in addition to adaptive reactions. Further adaptive effects included excessive augmentation of autophagosomes accompanied by increasing numbers of multivesicular bodies and intralysosomal myelin, invasion of macrophages and formation of macrophage centres, indicating the induction of cell-mediated unspecific immune response, which has already been reported in fish exposed to endosulfan (Ellis 1977).

The SER augmentation observed at levels $\geq 50 \mathrm{ng} \mathrm{l}^{-1}$ endosulfan is generally regarded as a sign of the induction of biotransformation processes (Hinton et al. 1978, Braunbeck et al. 1989, 1990a, b, c, Braunbeck \& Völkl 1991, 1993). In addition, transition of RER into concentric arrays has also been suggested to be indicative of mixed-function oxygenase (MFO) induction (Klaunig et al. 1979, Hawkes 1980) However, information about endosulfan metabolism by $\mathrm{MFO}$ enzyme systems is inconsistent. In rats, endosulfan has been reported to exert no effects (Dorough et al. 1978) or to be a weak inducer following single exposure (Gupta \& Gupta 1977, 1979). In contrast, endosulfan significantly stimulates MFO activities following repeated or chronic administration as in our experiment (Tyagi et al. 1984, 1985, Singh \& Pandey 1989). There is even more contradictory evidence for induction of cytochrome P-450 (for nomenclature, see Nebert et al. 1991) by phenobarbital-type inducers in fish: whereas

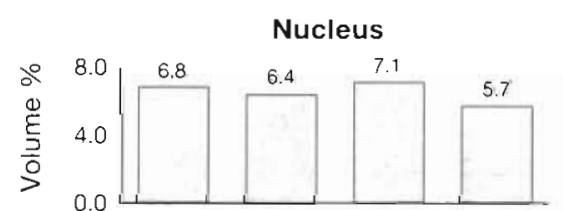

RER
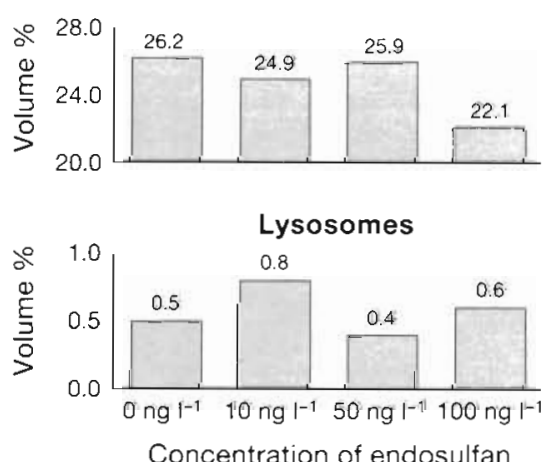

Concentration of endosulfan

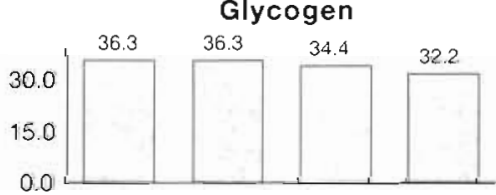

Mitochondria

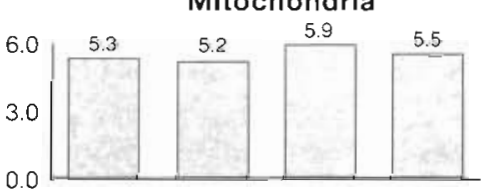

Peroxisomes

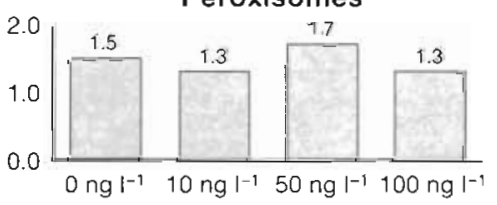

Concentration of endosulfan

Fig. 22. Oncorhynchus mykiss. Changes in relative volumes of selected cell components in hepatocytes of male rainbow trout following exposure to 0,10 , 50 , and $100 \mathrm{ng} \mathrm{l}^{-1}$ endosulfan for $28 \mathrm{~d}$ 
Goksøyr et al. (1987), Kleinow et al. (1987), Gooch et al. (1989), and Winston et al. (1989) failed to reveal such induction, other reports have suggested an induction by phenobarbital-type compounds (Gutman \& Kidron 1971, Burns 1976, Förlin \& Lidman 1978, Eisele et al. 1984, Bach \& Snegaroff 1989, van der Oost et al. 1990). Since Jensen et al. (1991) found stimulation not only of cytochrome P-450 IA1-related ethoxycoumarin-Odeethylase and aryl hydrocarbon hydroxylase activities, but also of aldrin epoxidase activities, the data presented in the present communication provide additional morphological evidence that endosulfan most likely does function as a mixed-type inducer of cytochrome P-450. However, since there appears to be a difference between the inducing potentials of technical and analytical grade endosulian (Jensen ei di. 1991), some of the SER proliferation observed in the present study might also have been due to impurities in the technical grade endosulfan used. In the case of endosulfan, biotransformation by rat as well as fish MFO enzyme systems would lead to a detoxification of the parent compound and the sulfate metabolite to less toxic derivatives such as the dial, lactone and ether form, which are readily excreted via bile, faeces, or, to a lesser extent, urine (Schoettger 1970, Dorough et al. 1978).

Increasing cellular heterogeneity, dilation of the nuclear envelope, progressive loss of mitochondrial integrity, myelin formation in peroxisomes and cytoplasm, and vesiculation and dilation of RER cisternae, which were observed at levels $\geq 50 \mathrm{ng} \mathrm{l}^{-1}$, are clearly degenerative effects. Dilation of intermembranous spaces in mitochondria, for example, was also observed in eel Anguilla anquilla exposed to the chemical spill at Basel in 1986 (Braunbeck et al. 1990a) and in eel and golden ide Leuciscus idus melanotus exposed to dinitro-o-cresol (DNOC; Braunbeck \& Völkl 1991, 1993), as well as in isolated hepatocytes of rainbow trout exposed to 4 -chloroaniline (Braunbeck 1993). Both DNOC and endosulfan are known to be uncouplers of oxidative phosphorylation (Dubey et al. 1984, Verschoyle et al. 1987). The mitochondrial effects observed may therefore represent the morphological counterpart of disturbances in mitochondrial respiration. Likewise, matrix heterogeneity and myelin formation in peroxisomes, as observed after exposure to $100 \mathrm{ng} \mathrm{I}^{-1}$ endosulfan, could also be a sign of physiological degeneration of peroxisomal functions.

The reduction in VLDL secretion by Golgi fields suggests changes in lipid metabolism and indicates a general reduction in the synthetic capacities of hepatocytes. Most of the hepatocellular effects observed in mitochondria, lysosomes, SER and RER are well known responses to other toxicants in the liver of rainbow trout (Arnold \& Braunbeck 1995) as well as of other fish species (Braunbeck et al. 1990a, b,c, Braunbeck \& Völkl 1993, Braunbeck 1994). These effects must therefore to be classified as unspecific. Although this restriction limits their use for the diagnostic discrimination of particular chemical compounds in the field, they may be used to identify the biological detection limit of toxicant effects. In addition, they represent highly sensitive biomarkers of general environmental contamination well below lethal concentrations.

\section{CONCLUSIONS}

The results document toxic effects of endosulfan in rainbow trout liver at concentrations of $10 \mathrm{ng} \mathrm{l}^{-1}$, i.e. weli beiow the $\mathrm{LC}_{50}$ of $1.4 \mu \mathrm{g} \mathrm{\textrm {i } ^ { - 1 }}$ endosulfan (Johnson \& Finley 1980). The almost complete lack of stereological alterations, contrasted with the numerous qualitative changes, indicates that qualitative histo- and cytopathology may not simply be reduced to quantitative data. Whereas effects at $10 \mathrm{ng} \mathrm{l}^{-1}$ endosulfan suggested only low toxicity, progressive alterations at higher exopsure levels indicate enhanced toxicity of endosulfan above $50 \mathrm{ng} \mathrm{l}^{-1}$. Pathological changes in mitochondria and peroxisomes most likely represent the morphological counterpart of disturbances in mitochondrial respiration as one possible mechanism of endosulfan intoxication. The results further are consistent with endosulfan as a mixed-type inducer of MFO systems in fish hepatocytes.

Acknowledgements. This investigation was supported by a grant from the Sandoz Rheinfonds under contract from May 1991. The authors express their cordial thanks to Mrs $G$. Adam for excellent assistance in photographic reproduction.

\section{LITERATURE CITED}

Arnold H, Braunbeck T (1995) Disulfoton as a major toxicant in the chemical spill at Basel in November 1986: acute and chronic studies with eel and rainbow trout. In: Müller $R$, Lloyd R (eds) Sublethal and chronic effects of pollutants on freshwater fish. Blackwell, Oxford, p 79-86

Bach J, Snegaroff J (1989) Effects of the fungicide perchloraz on xenobiotica metabolism in rainbow trout: in vivo induction. Xenobiotica 19:1-9

Baier C, Hurle K, Kirchhoff J (1985) Datensammlung zur Abschätzung des Gefährdungspotentials von Pflanzenschutzmittel-Wirkstoffen für Gewässer DVWK Schriften 74. Parey, Hamburg

Bowen ID (1984) Laboratory techniques for demonstrating cell death. In: Davies I, Sigee DC (eds) Cell ageing and cell death. Cambridge University Press, Cambridge, p 5-40

Braunbeck T (1993) Cytological alterations in isolated hepatocytes from rainbow trout (Oncorkynchus mykiss) exposed in vitro to 4-chloroaniline. Aquat Toxicol 25:83-110

Braunbeck T (1994) Detection of environmentally relevant pesticide concentrations using cytological parameters: 
pesticide specificity in the reaction of rainbow trout liver? In: Müller R, Lloyd R (eds) Sublethal and chronic effects of pollutants on freshwater fish. Blackwell, Oxford, p 15-29

Braunbeck T, Arnold H, Burkhardt-Holm P (1994) Subletale Veränderungen bei Fischen durch Pestizide. SandozRheinfonds, Basel, p 60-67

Braunbeck T, Burkhardt-Holm P. Storch V (1990a) Liver pathology in eels (Anguilla anguilla $\mathrm{L}$ ) from the Rhine river exposed to the chemical spill at Basel in November 1986. Limnologie aktuell 1:371-392

Braunbeck T, Görge G. Storch V, Nagel R (1990b) Hepatic steatosis in zebra fish (Brachydanio rerio) induced by long-term exposure to -hrxachlorocyclohexane. Ecotoxicol Environ Safety 19:355-374

Braunbeck T, Storch V, Bresch H (1990c) Species-specific reaction of liver ultrastructure in zebrafish (Brachydanio rerjo) and trout (Salmo gairdneri) after prolonged exposure to 4-chloroaniline. Arch Environ Contam Toxicol 19: $405-418$

Braunbeck T, Storch V, Nagel R (1989) Sex-specific reaction of liver ultrastructure in zebrafish (Brachydanio rerio) after prolonged sublethal exposure to 4 -nitrophenol. Aquat Toxicol 14:185-202

Braunbeck T, Völkl A (1991) Induction of biotransformation in the liver of eel (Anguilla anguilla L.) by sublethal exposure to dinitro-o-cresol (DNOC): an ultrastructural and biochemical study. Ecotoxicol Environ Safety 21:109-127

Braunbeck T, Volkl A (1993) Cytological alterations in the livers of golden ide (Leuciscus idus melanotus) and eel (Anguilla anguilla) induced by sublethal doses of dinitroo-cresol. In: Braunbeck T, Hanke W, Segner H (eds) Fish in ecotoxicology and ecophysiology. Verlag Chemie, Weinheim, p 55-80

Burns KA (1976) Microsomal mixed function oxidases in an estuarine fish, Fundulus heteroclitus, and their induction as a result of environmental contamination. Comp Biochem Physiol 53B:443-446

Couch JA, Courtney LA (1987) N-Nitrosodiethylamineinduced hepatocarcinogenesis in estuarine sheepshead minnow (Cyprinodon varlegatus): neoplasms and related lesions compared with mammalian lesions. J Natl Cancer Inst 79:297-321

Dange AD (1986) Changes in carbohydrate metabolism in tilapia, Oreochromis mossambicus, during short-term exposure to different types of pollutants. Environ Pollut $41 \mathrm{~A}: 165-177$

Deutsche Kommission zur Reinhaltung des Rheins (1986) Deutscher Bericht zum Sandoz-Unfall mit Meßprogramm. DKRR

Dorough HW, Huhtanen K, Marshall TC, Bryant HE (1978) Fate of endosulfan in rats and toxicological considerations of apolar metabolites. Pestic Biochem Physiol 8:241-252

Dubey RG, Beg MU, Singh J (1984) Effects of endosulfan and its metabolites on rat liver mitochondrial respiration and enzyme activities in vitro. Biochem Pharmacol 33: $3405-3410$

Eisele TA, Coulombe RA, Pawlowski NE, Nixon JE (1984) The effects of route of exposure and combined exposure of mixed function oxidase inducers and suppressors on hepatic parameters in rainbow trout (Salmo gairdneri). Aquat Toxicol 5:211-226

Ellis AE (1977) The leucocytes of fish: a review. J Fish Biol 11:453-491

Elskus AA, Stegeman JJ (1989) Further consideration of phenobarbital effects on cytochrome P-450 activity in the killifish, Fundulus heteroclitus. Comp Biochem Physiol 92C: $223-230$
Ferrando MD, Andreu-Moliner E, Almar MM, Cebrian C, Nunez A (1987) Acute toxicity of organochlorinated pesticides to the European eel (Anguilla anguilla). The dependency on exposure time and temperature. Bull Environ Contam Toxicol 39:365-369

Förlın L, Lidman U (1978) Effects of clophen A50, 4-, 2, 5, 2', 5' tetra- and $2,4,5,2^{\prime}, 4^{\prime}, 5^{\prime}$-hexachlorobiphenyl on the mixed function oxidase system in rainbow trout (Salmo gairdneri, Rich.). Comp Biochem Physiol 60C:193-197

Frank R, Braun HE, van Hove Holdrinet $M$, Sirons GJ, Ripley BD (1982) Agriculture and water quality in the Canadian Great Lakes Basin: pesticide use in 11 agricultural watersheds and presence in stream water, 1975-1977. J Environ Qual 11:497-505

Gill TS, Pande J, Tewari H (1991) Effects of endosulfan on the blood and organ chemistry of freshwater fish. Barbus conchonius Hamilton. Ecotoxicol Environ Safety 21:80-91

Gluth G, Hanke W (1985) A comparison of physiological changes in carp. Cyprinus carpio, induced by several pollutants at sublethal concentrations. Ecotoxicol Environ Safety 9:179-188

Goebel H, Gorbach S, Knauf W, Rimpau RH, Huttenbach H (1982) Properties, effects, residues, and analytics of the insecticide endosulfan. Residue Rev 83:1-165

Coksøyr A, Andersson T. Hansson T, Klungsøyr J, Zhang $Y$, Förlin L (1987) Species characteristics of the hepatic xenobiotic and steroid biotransformation systems of two teleost fish. Atlantic cod (Gadus morhua) and rainbow trout (Salmo gairdneri). Toxicol Appl Pharmacol 89:347-360

Gooch JW, Elskus AA, Kloepper-Sams PJ, Hahn ME, Stegeman JJ (1989) Effects of ortho- and non-ortho-substituted polychlorinated biphenyl congeners on the hepatic monooxygenase system in scup (Stenotomus chrysops). Toxicol Appl Pharmacol 98:422-433

Greve PA, Wit SL (1971) Endosulfan in the Rhine river J Water Poliut Contr Fed 43:1338-1348

Gupta PK, Gupta RC (1977) Influence of endosulfan on pentobarbitone sleeping time and blood and brain concentration in male rats. J Pharm Pharmacol 29:245-246

Gupta PK, Gupta RC (1979) Pharmacology, toxicology and degradation of endosulfan, a review. Toxicology 13 : $115-130$

Gutman Y, Kidron M (1971) Liver N-demethylating activitytemperature effect and phenobarbital induction in different species. Biochem Pharmacol 20:354.7-3550

Hacking MA, Budd J, Hodson K (1978) The ultrastructure of the liver of the rainbow trout: normal structure and modifications after chronlc administration of a polychlorinated biphenyl Aroclor 1254. Can J Zool 56:477-491

Hampton JA, Lantz RC, Goldblatt PJ, Laurén DJ, Hinton DE (1988) Functional units in rainbow trout (Salmo gairdneri, Richardson) liver: II. The biliary system. Anat Rec 221. $619-634$

Hampton JA, McCuskey PA, McCuskey RS, Hinton DE (1985) Functional units in rainbow trout (Salmo gairdnen) liver. I. Arrangement and histochemical properties of hepatocytes. Anat Rec 213:166-175

Hanke W, Gluth G, Bubel H, Müller R (1983) Physiological changes in carps induced by pollution. Ecotoxicol Environ Safety 7:229-241

Hawkes JW (1980) The effects of xenobiotics on fish tissues: morphological studies. Fed Proc 39:3230-3236

Herzel F (1972) Organochlorine insecticides in surface waters in Germany-1970 and 1971. Pestic Monit J 6:179-187

Hinton DE, Klaunig JE, Lipsky MM (1978) PCB-induced alterations in teleost liver: a model for environmental disease in fish. Mar Fish Rev 40:47-50 
Hinton DE, Lantz RC, Hampton JA, McCuskey PR, McCuskey RS (1987) Normal versus abnormal structure: considerations in morphologic responses of teleosts to pollutants. Environ Health Perspect 71:139-146

Hinton DE, Laurén DJ (1990) Liver structural alterations accompanying chronic toxicity in fishes: potential biomarkers of exposure. In: McCarty JF, Shugart LR (eds) Biomarkers of environmental contamination. Lewis Publishers, Boca Raton, p 15-57

Holcombe GW, Phipps GL, Tanner DK (1982) The acute toxicity of kelthane, dursban, disulfoton, pyrdin and permethrin to fathead minnows Pimephales promelas and rainbow trout Salmo gairdneri. Environ Poll 29:167-178

Janardan SK, Olson CS, Schaeffer DJ (1984) Quantitative comparisons of acute toxicity of organic chemicals to rat and fish. Ecotoxicol Environ Safety 8:531-539

Jensen EG. Skaare JU, Egaas E, Goksøyr A (1991) Resporise of xenobiotic metabolizing enzymes in rainbow trout (Oncorhynchus mykiss) to endosulfan, detected by enzyme activities and immunochemical methods. Aquat Toxicol 21:81-92

Johnson WW, Finley MT (1980) Handbook of acute toxicity of chemicals to fish and aquatic invertebrates. US Dept Int Fish Wildl Serv Res Publ 137:1-98

Joshi AG, Amminikutty J, Rege MC (1981) Chronic toxicity of some pesticides for estimating MATC for two freshwater fishes. J Environ Biol 2:43-57

Karnovsky MJ (1971) Use of ferrocyanide-reduced osmium tetroxide in electron microscopy. J Cell Biol 51:284 (abstract 164)

Klaunig JE, Lipsky MM, Trump BF, Hinton DE (1979) Biochemical and ultrastructural changes in teleost liver following subacute exposure to PCB. J Environ Pathol Toxicol 2:953-963

Kleinow KM, Melancon MJ, Lech JJ (1987) Biotransformation and induction: applications to toxicity, bioaccumulation and monitoring of environmental xenobiotics in fish Environ Health Perspect 71:105-119

Korn S, Earnest R (1974) Acute toxicity of 20 insecticides to striped bass, Morone saxatilis. Calif Fish Game 60:128-131

Le Hir M, Herzog V, Fahimi HD (1979) Cytochemical detection of catalase with 3,3'-diaminobenzidine. A quantitative reinvestigation of the optimal assay conditions. Histochemistry 64:51-66

Matthiessen P, Roberts R (1982) Histopathological changes in the liver and brain of fish exposed to endosulfan insecticide during tsetse fly control operations in Botswana. J Fish Dis 5:153-159

Mayer FL, Ellersieck MR (1986) Manual of acute toxicity: interpretation and data base for 410 chemicals and 66 species of freshwater animals. US Dept Int Fish Wildl Serv Res Publ 160

Miranda CL, Wang JL, Henderson MC, Buhler DR (1990) Immunological characterization of cytochrome P-450 from rainbow trout. Evidence for homology with phenobarbitalinduced rat P-450s. Biochim Biophys Acta 1037:155-160

Murty AS, Devi P (1982) The effect of endosulfan and its isomers on tissue protein, glycogen, and lipids in the fish Channa punctata. Pestic Biochem Physiol 17:280-286

Nebert DW, Nelson DR, Coon MJ, Estabrook RW, Feyereisen R, Fujii-Kuriyama Y, Gonzalez FJ, Guengerich FP, Gunsalus IC, Johnson EF, Loper JC, Sato R, Waterman EF, Waxman DJ (1991) The P-450 superfamily: update on new sequences, gene mapping, and recommended nomenclature. DNA 10:1-14

Paul D, Raut SK (1987) Comparative studies on the toxicity of endosulfan in some freshwater fishes under different $\mathrm{pH}$ and hardness of water. Curr Sci 56:315-316

Schimmel SC, Patrick JM, Forester J (1977) Toxicity and bioconcentration of $\mathrm{BHC}$ and lindane in selected estuarine animals. Arch Environ Contam Toxicol 6:355-363

Schoettger RA (1970) Toxicology of Thiodan in several fish and aquatic invertebrates. US Dept Int Fish \& Wildlife Serv, Invest Fish Control 35:31 pp

Singh I (1964) A modification of the Masson-Hamperl method for staining of argentaffin cells. Anat Anz 115:81-82

Singh SK, Pandey RS (1989) Toxicity of endosulfan on kidney of male rats in relation to drug metabolizing enzymes and microsomal lipid peroxidation. Indian J Exp Biol 27: $725-728$

Stegeman JJ (1989) Cytochrome P-450 forms in fish: catalytic, immunological and sequence similarities. Xenobiotica 19: $1093-1110$

Tyagi SR, Sriram K, Narayan S, Misra UK (1985) Induction of cytochrome P-450 and phosphatidylcholine synthesis by endosulfan in liver of rats: effects of quality of dietary proteins. J Environ Sci Health 20B:651-664

Tyagi SR, Yogendra Singh PK Srivastava, Misra UK (1984) Induction of hepatic mixed function oxidase system by endosulfan in rats. Bull Environ Contam Toxicol 32:550-556

van der Oost $R$, Heida $H$, Opperhuizen $A$, Vermeulen NPE (1990) Interrelationships between bioaccumulation of organic trace pollutants (PCBs, organochlorine pesticides and PAHs), and MFO-induction in fish. Comp Biochem Physiol 100C:43-47

van Dyk LP. Greeff CG (1977) Endosulfan pollution of rivers and streams in the Loksop Dam cotton-growing area. Agrochemophysica 9:71-75

Verma SR, Rani S, Tonk IP, Dalela RC (1983) Pesticideinduced dysfunction in carbohydrate metabolism in three freshwater fishes. Environ Res 32:127-133

Verschoyle RD, Brown AW, Ray DE, Bird I (1987) The relationship between uncoupling of oxidative phosphorylation and neuronal necrosis within the CNS in rats dosed with trihalogenated imidazoles. Toxicol Appl Pharmacol 89: $175-182$

Verschueren K (1983) Handbook of environmental data on organic chemicals, 2nd edn. Van Nostrand-Reinhold, New York

Wall GJ, Wilding LP, Smeck NE (1978) Physical, chemical, and mineralogical properties of fluvial unconsolidated bottom sediments in northwestern Ohio.J Environ Qual $7: 319-325$

Wegmann RCC, Greve PA (1978) Organochlorines, cholinesterase inhibitors, and aromatic amines in Dutch water samples, September 1969-December 1975. Pestic Monitor J 12:149-162

Weibel ER (1979) Stereological methods, Vol I. Academic Press, New York

WHO (1984) Environmental Health Criteria 40. Endosulfan. World Health Organization, Geneva

WHO (1986) Environmental Health Criteria 63. Organophosphorous insecticides: a general introduction. World Health Organization, Geneva

Winston GW, Narayan S, Henry CB (1989) Induction pattern of liver microsomal alkoxyresorufin-O-deethylase of channel catfish (Ictalurus punctatus): correlation with PCB exposure in situ. J Environ Sci Health 24B:277-289

Wyllie AH, Duvall E, Blow JJ (1984) Intracellular mechanisms in cell death in normal and pathological tissues. In: Davies I. Sigee DC (eds) Cell ageing and cell death. Cambridge University Press, Cambridge, p 269-294 